\title{
Influence of Pre-question and genre-based instructional strategies on reading
}

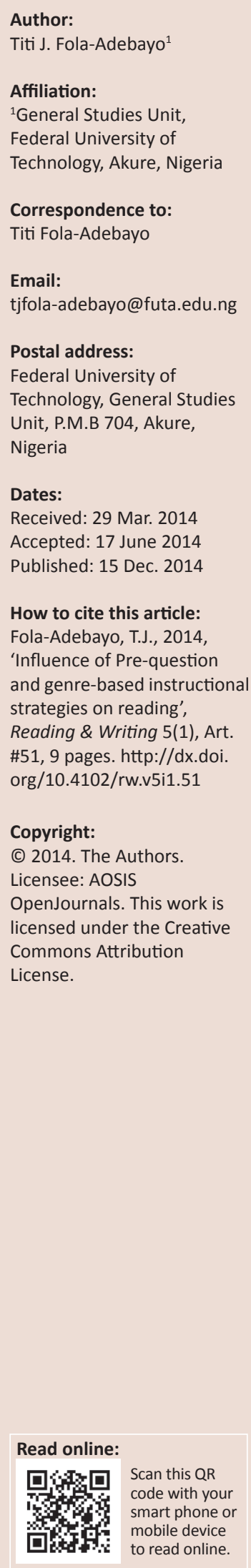

This study investigated the influence of Pre-question and genre-based instructional strategies on science undergraduates' achievement in, and attitude to, reading. Using purposive sampling, two specialised universities in Nigeria were selected and stratified sampling was employed in assigning students to research groups based on gender and performance in a verbal ability test. Two hundred and eighty-five students participated in the study. Pre-post randomised block experimental design was used with three experimental groups and one control group. The experimental procedure involving Pre-question, genre-based instruction and a combination of Pre-question and genre-based instructional strategies were used for the experimental groups for four weeks whilst the control group received normal teacher input. Data were collected through a Reading Comprehension Achievement Test and Students' Attitude Questionnaire. Qualitative data, obtained from videotapes of classroom interactions, were subjected to conversation and interaction analyses and quantitative data were analysed with Analysis of Covariance (ANCOVA). The results indicate that although there was no significant main effect of instructional strategy on students' achievement in reading comprehension, there was significant main effect of instructional strategy on students' attitude to reading $\left(F_{(3,231)}=30.9\right.$; $p<.05)$. Findings from the qualitative enquiry revealed that female students were more voluble and assertive in their responses probably because of the need to resist male domination whilst male students used discourse strategies to affirm their authority. The study indicated that the combination of pre-question and genre-based approach was the most effective in enhancing the students' attitude to reading. Reading is one of the most useful of the Language Arts skills which learners need for academic reasons and for lifelong learning. The globalised world demands that the second language student of science and technology demonstrates competence in reading materials in his specialist area in order to participate fully in his discourse community.

\section{Introduction}

Reading problems are a global issue. Hock and Mellard (2005:192) referred to the National Adult Literacy Survey which revealed 'that nearly half of all adults in the United States of America, or 90 million people, scored in the two lowest levels of functional literacy' and over half of this population (58\%) were 'between 16 and 55 years old', a figure which represents today's workforce. Similarly, the Program for International Student Assessment (PISA) revealed that many students functioned below the baseline of proficiency in 2009 in the '65 countries that make up the Organisation for Economic Co-operation and Development' (Fleischman, Hopstock, Pelczar \& Shelley 2010:4). The problem is not limited to these environments as Wils et al. (2003, cited in Blumberg 2007:4) observed in their study involving the analysis of sixteen countries drawn from South Asia, sub-Saharan Africa, the Middle East and North African countries, that 'only 37.44 percent of boys and 33.25 percent of girls were able to read by the time they completed primary school'. Obah (1981) in her study of the text processing strategies of Nigerian undergraduates describes these neophytes as non-thinking readers.

Reading is an important medium of learning in tertiary education, Carrell (1988:1) comments on its importance in the observation that, ' $f$ ] or many students, reading is by far the most important of the four skills in a second language, particularly in English as a second or foreign language'. In spite of its importance, reading is poorly taught in many Nigerian schools, resulting in the poor academic achievement of the students. The poor performance of the Nigerian undergraduate in the English Language, the language in which academic material in tertiary level is read, has always engaged the attention of the government, parents and researchers in particular. Work in the different language skill areas attests to the students' poor academic performance. For instance, scholars have indicated that the students' performance in reading comprehension has been on the decline Unoh (1980), Nzinga (1983), Bodunde (2006); similarly, a downward trend in the English Language was also observed in the writing skills of students (Odejide 1979). 
The poor state of reading in Nigeria is caused by a lack of knowledge of relevant reading strategies. Closely related to this is that, in some situations, the teaching of reading is not theory-based and research findings are not operationalised in some textbooks. In fact, researchers (Odejide 2003; Oyetunde 2002) claim that many teachers of language, including English Language in tertiary institutions in Nigeria, are not aware of the theories, methods or principles of second language teaching. More specifically, Oyetunde (2002) asserts that instructional practices in most schools are too confused to be defined and that instructional and methodological deficiencies cause reading and communication failure amongst students.

English is the language of the elite in ESL situations. Canagarajah (2002), cited in Templer (2004:2), rightly observes that it, 'has risen to near total hegemony as a kind of linguistic Tyrannosaurus Rex'. It has dominated academic communication globally and the ability to read effectively in English is a necessary requirement for socialising and involving students in the international community of Science and Technology.

The quest by developing countries, such as Nigeria, for technological development demands that the second language learner of English, particularly the science student, must show competence in English Language skills. Proficiency in these skills will help such a student to improve his or her understanding of the discipline and participate fully in all the domains of a technological culture. The student of Science, Technology and Agriculture needs competence in the English Language skills, particularly in reading, to be of relevance and service to his community.

The globalised world with its emphasis on the acquisition of knowledge, places extra demands on the undergraduate of science and technology, particularly the second language learner who must exert cognitive effort in reading material, in their area of study, in a second language. For this undergraduate, there is a need for a high level of literacy and an increasing capacity to comprehend complex texts, especially in the subsequent years of university education, when subject-specific content materials are central to learning and the curriculum.

In spite of its importance reading, particularly in the domain of science and technology, poses a challenge for the second language learner, who faces the problem of a more advanced conceptual difficulty in his subject area, studying through the medium of a second language as well as poor reading skills. Therefore, training in the use of appropriate reading strategies is important if students of science, technology and agriculture are to benefit from reading in subject-specific areas. Apart from the usefulness of training in the use of reading strategies for students of SciTech, students of English as a Second Language (ESL) will benefit from this kind of training as 'high levels of English Language literacy ... have been found to correlate with frequent and complex strategy use' (Zhang \& Wu 2009:37).
Scholars, who research reading, in Nigeria have performed extensive work on reading improvement through the application of different reading strategies, but their efforts have been directed at strategy instruction in secondary schools (Isuigo-Abanihe 1991; Adesemewo 1999; Nwosu 2002; Odiaka 2002; Tswanya 1995; Jiboku 1998; Udosen 2002). Studies on the application of reading strategies for undergraduates are scanty. In particular, the areas of Pre-question and genrebased instruction, alongside the qualitative investigation of gender and reading, have witnessed little research attention. Even studies on discourse frameworks, particularly genre theory and reading, have not received much attention in second language research although much work has been carried out in the first language (Trabasso \& Bouchard 2002; Grabe 2004; Kintsch \& Rawson 2005; Perfetti, Landi \& Oakhill 2005). Given the strong claims for the effectiveness of discourse organisation in reading comprehension in L1, this study seeks to generalise the results of genre analysis and reading to an L2 context. Except for the related work of Obah (1981) and Adelabu (1998), studies matching Pre-question and genre knowledge with the comprehension of science texts, by Nigerian undergraduates, in specialised universities (i.e. Universities of Science, Technology and Agriculture) are few. The lack of studies that combine schema and genre frameworks in teaching reading presents a gap in knowledge that this study endeavours to fill.

Against the background of the issues discussed so far, this study investigated the influence of Pre-question and genre-based instruction on the achievement of science undergraduates in reading comprehension and their attitude to reading.

\section{Theoretical Framework}

The theoretical orientations that ground this research include: schema, genre and attitude theories. The first to be discussed is schema theory.

\section{Schema theory and reading comprehension}

Rumelhart (1984:2) defines schema as, 'data structures for representing the generic concepts stored in memory.' That is, it indicates the relationships that exist between the component parts of an event. The concept of schema theory has a pervasive influence on notions of reading and it has formed the framework of several empirical studies in the domain (Devine 1988; Alderson \& Urquhart 1988; Steffensen \& Joag-Dev 1984). The notion of schema in reading suggests that it is an interactive process involving conceptual and textual processes functioning interactively.

The major strength of schema theory is that presenting readers with reading material which is congruent with their pre-existing schema will, to a large extent, facilitate reading comprehension. Although Anderson (1984) asserts that activation of background knowledge has facilitative effects on the act of comprehending and remembering, some readers may demonstrate poor comprehension and memory skills; 
this is not because of deficits in comprehension and memory, but because they lack the background knowledge or fail to activate the background knowledge that was presupposed by the text. This limitation notwithstanding, schema theory underscores the role of background knowledge in reading comprehension.

Influenced by the developmental perspective on reading, the RAND Reading Study Group (2002) defines reading comprehension as follows:

[T] he process of simultaneously extracting and constructing meaning through interaction and involvement with written language. We use the words extracting and constructing to emphasize both the importance and the insufficiency of the text as a determinant of reading comprehension. (p. 11)

The group's working definition of the term involves three key elements: the reader, the text and the activity, which contributes to comprehension (RAND 2002:11). The group asserts that reading comprehension is a complex cognitive process that draws on a wide range of skills and knowledge.

\section{Genre theory and reading comprehension}

Swales's work (1981) provides the first known work in genre analysis. He applied the approach to the analysis of forty-eight introductions of journal articles drawn from: the Hard Sciences, Biology, Medicine, the Social Sciences and Language. His work which focused on the introduction section of the research article genre suggests 'a three move schema' for characterising the introductions of research articles. He proposed the Creating a Research Space model which is outlined below:

- 'Move 1 - Establishing a Territory'

- 'Move 2 - Establishing a Niche'

- 'Move 3 - Occupying the Niche' (Swales 1990:141).

Applied linguists, ESP (English for Specific Purposes) researchers and practitioners (Dudley-Evans 1987; Cheung \& Ching 1997; Nwogu 1991) claim that Swales's genre analysis is very useful for analysing texts in ESP and EST (English for Science and Technology) situations. The approach holds pedagogic potential. In fact, several studies have established empirical evidence linking genre knowledge with improved reading recall and composition (Bhatia 1993; Cheung \& Ching 1997; Hyon 2001). The genre framework, however, shows some weakness: it appears prescriptive and rigid, research articles vary across disciplines and mastery of the Swalean template may not allow students to develop a critical relationship with their subject matter, or at finding the language with which to express the same. These identified weaknesses, however, do not invalidate Swales's model.

\section{Reading attitude and reading comprehension}

Attitude is a psychological construct that plays a key role in moderating a reader's 'level of motivation, intention to read' and the 'relationship between an individual's beliefs and reading activities' (Petscher 2010:335). Cognitive, affective and conative aspects have been used to describe the concept of attitude (Mathewson 2004). McKenna, Conradi, Lawrence, Jang and Meyer explain attitudes to reading as follows:

We define reading attitudes as acquired predispositions to respond in a consistently favorable or unfavorable manner with respect to aspects of reading. We employ the plural term, attitudes, because although a general attitude toward reading exists in a hierarchical structure, it is more useful to situate it within the medium in which reading will be done and the purposes it will serve. (McKenna et al. 2012:285)

Mathewson (1994:1434) presents a tricomponent view of attitude 'with evaluation as the cognitive component, feeling as the affective component, and action readiness as the conative component'. Mathewson (1994) explains that these components impact on the intention to read or continued reading and they affect attention, use of strategy and reading comprehension. Attitude is closely related to performance in reading comprehension and the link between attitude and reading behaviour is intention to read and influences that promote the formation of positive intention to read.

Reading is a complex process which involves affect and cognition and scholars acknowledge that students' attitude to reading exerts significant influence on their reading achievement (Russ 1989). Reading attitudes are learnt characteristics that are influenced by societal, family and school-based factors (Baker 2003) and these factors influence students' perception about themselves as readers, and the degree to which they are motivated to engage in reading. Students' attitude to reading has a positive effect on reading engagement and achievement in reading (McKenna, Kear \& Ellsworth 1995). Some empirical studies on reading instruction and attitude to reading reveal that training in reading or even exposure to extensive reading enhances reading performance, and also leads to a positive attitude to reading (Adelabu 1998; Jiboku 1998; Yamashita 2004; Butler 2007).

\section{Methodology Hypotheses}

In order to address the concerns of this research, the following hypotheses were tested:

Ho1: There is no significant effect of instructional strategy on the achievement of undergraduates in reading comprehension.

Ho2: There is no significant effect of instructional strategy on the attitude of undergraduates to reading.

\section{Design}

The study adopted a pre-post randomised blockexperimental design involving three experimental groups and one control group. The three experimental groups were exposed to different treatments: Pre-question (P), Genrebased instruction $(\mathrm{G})$ and a combination of Pre-Question and genre-based instruction $(\mathrm{P} / \mathrm{G})$. The control group $(\mathrm{C})$ 
received no input from the teacher. The four groups were exposed to pre-test and post-test conditions.

\section{Variables}

\section{Independent variables}

Three independent variables which operated at three levels were used:

- Pre-Question (P)

- Genre-based instruction (G)

- The combination of Pre-question and genre-based instruction, henceforth referred to as Pre-Question and Genre (P/G).

\section{Dependent variables}

The dependent variables were:

- Achievement or performance in reading comprehension, this was ranked as high, average and low.

- Attitude to reading which also operated at three levels: positive, neutral and negative.

\section{Moderating variables}

The moderating variables were:

- Verbal ability - This refers to the ability to comprehend written passages, work out the meaning of lexical items and establish syntactic and semantic relations in texts. This ability was ranked as high, average and low.

- Gender - This takes into account biologically determined sex such as male or female and the socially constructed characteristics or roles assigned to males and females in society. These roles influence social and classroom behaviour.

\section{Population and sample}

First year undergraduates of the Federal University of Technology, Minna, (FUTM) Nigeria, and the Federal University of Agriculture, Abeokuta, (FUNAAB) Nigeria, participated in the study. Each university represented one University of Technology and one University of Agriculture. Using a purposive sampling procedure, drawn from the sampling frame of students who were admitted into the Universities through the Joint Admission and Matriculation Board Examination (JAMB), two hundred and eighty-five students (285 involving 146 males and 139 females) were selected from the two universities. These numbers consisted of 72 male and 70 female students who took part in the study in Minna, whilst 74 male and 69 female students from Abeokuta participated in the study.

Stratified sampling was employed in assigning students to the research groups and the strata were defined by gender and performance in a verbal ability test which was administered to the students. Those in the high verbal ability groups obtained scores of $60 \%$ and above; the average verbal ability group scored $50 \%-59 \%$, whilst the low verbal ability group obtained $49 \%$ and below. The sample comprised freshmen from departments related to Biology and Agriculture. Students from these departments were chosen to ensure that they had necessary background knowledge to comprehend the reading materials.

\section{Research instruments}

Four research instruments were validated and used for the pilot study; they were later modified and employed for the main study:

- Reading passages

- Instruction guide (Pre-question and Genre-based instruction)

- Reading comprehension achievement tests

- Verbal ability test.

\section{The reading comprehension passages}

The reading comprehension passages used for this study were obtained from introductory textbooks used by students of the Biological Sciences and Agriculture in Specialised Federal Universities in Nigeria. The choice of the recommended texts was based on the demands of ESP for genuine and relevant texts (Robinson 1991). Information on the selected books is presented in Table 1.

ESP commercial books written by foreign authors, Kay (1985) and Adkins and McKean (1983), were included because of the likely familiarity of the topics to the students (Bats, the World of Microbes and Whales). The condition for selecting a book amounted to it having been written by a Nigerian or an African. The selection of books written by these authors was to ensure that both the topic and language were familiar to the students. The close procedure was used to select readable

TABLE 1: Selected books with target audience and readability level.

\begin{tabular}{|c|c|c|c|c|c|}
\hline Serial number & Author & Title of book & Publisher & Target audience & Readability level \\
\hline 1 & Ewusie (1980) & Tropical biology & Harrap Ltd. & Ordinary level and school certificate & 43.8 \\
\hline 2 & Segun (1998) & Tropical zoology & University Press Plc & $\begin{array}{l}\text { Students in Colleges; } \\
\text { Polytechnicsand undergraduates }\end{array}$ & 41.2 \\
\hline 3 & $\begin{array}{l}\text { Osundina, Oloke, Fawole } \\
\text { and Liasu (1998) }\end{array}$ & Diversity of organisms & $\begin{array}{l}\text { Y-Books, Associated Book- } \\
\text { Makers, Nigeria Ltd. }\end{array}$ & Undergraduates & 34.8 \\
\hline 4 & Olorode and IIloh (2000) & $\begin{array}{l}\text { Variety of forms in the plant } \\
\text { kingdom }\end{array}$ & $\begin{array}{l}\text { Bola Kay Color Prints \& } \\
\text { Publishers }\end{array}$ & $\begin{array}{l}\text { Colleges of Education, Colleges of } \\
\text { Agriculture, undergraduates }\end{array}$ & 39 \\
\hline 5 & Kay (1985) & $\begin{array}{l}\text { Biological sciences: } \\
\text { Developing reading skills in } \\
\text { English }\end{array}$ & Pergamon Press Ltd. & Advanced learners and professionals & - \\
\hline 6 & $\begin{array}{l}\text { Adkins and McKean } \\
\text { (1983) }\end{array}$ & $\begin{array}{l}\text { Text to note: Study skills for } \\
\text { advanced learners }\end{array}$ & $\begin{array}{l}\text { Edward Arnold Publishers } \\
\text { Ltd. }\end{array}$ & $\begin{array}{l}\text { Advanced Learners in Colleges } \\
\text { of Higher Education and } \\
\text { undergraduates }\end{array}$ & - \\
\hline
\end{tabular}


passages from each book and to determine their readability levels. The readability test carried out amongst students of the Federal University of Technology Akure ranged from 34.8-43.8. These scores on the readability scale indicate that students would be able to use the materials for instructional purposes even though some guidance would be needed to help them master the demands of reading the texts.

\section{Reading comprehension questions}

The reading comprehension which was set to cover 'three levels of comprehension: textually explicit, textually implicit and scriptally implicit questions' (Pearson \& Johnson 1978:139) were obtained from the passages selected from the readability test. Textually explicit questions are text based, and they require decoding skills and knowledge of the grammatical relations of words to each other in sentences and larger texts. Textually implicit questions require reading between the lines, and processing these questions demands combining textual information with the students' background knowledge. Scriptally implicit questions require extra textual knowledge; they require analysing, evaluating and reacting personally to information in the text. About thirty and thirty-five questions were set on each of the passages and the questions included: questions requiring true or false responses, short answer questions, questions requiring table completion, lexical cohesion, outlining, decoding word meaning and analysing words into their constituent parts.

\section{Verbal ability test}

Performance in the verbal ability test was used to put students into the various verbal ability groups. The test items for this instrument were drawn from the syllabi of the Joint Admissions and Matriculation Board (JAMB) and PreDegree English of the Federal Universities of Technology in Akure, Minna and the Federal University of Agriculture, Abeokuta. The test had one hundred items and each was rated one mark. Items tested include: the ability to reason, interpret, summarise and make inferences; a familiarity with the lexis and structure of the English Language was also tested. Performance in the test was used to categorise the participants into three verbal ability groups: high (60\% and above), average (50\% - 59\%) and low ( $49 \%$ and below). Using the Kuder-Richardson formula 20 (KR-20), an appropriate reliability of $\mathrm{KR}=.87$ was found and the questions had an average item difficulty of .47 which proved that the items were appropriate.

\section{Gender}

The concept of gender 'refers to a system of socially defined roles, privileges, attributes and relationships between men and women which are learned and not biologically determined' (Khamati-Njenga \& Clancy 2005:5). Sex is the biological differentiation between male and female whilst gender refers to the differentiation between masculinity and femininity; the latter is constructed through socialisation, religion and education. Gender in this study is considered a social construct that subsumes biologically determined sex, such as male or female, and the socially constructed characteristics or roles assigned to males and females in society. These roles influence social and classroom behaviour.

The current study employed discourse and conversation analysis to investigate gender discourse and gender relations in two Nigerian English for Academic Purposes (EAP) reading classrooms. The difference view on gender research (Cameron 1998; Tannen 2003) was adopted in this study and the analysis revolved around issues of difference between male and female speech. The interaction took into account how gender identities were formed, maintained and even challenged and the interactional means used to achieve this.

\section{Teaching plan used for the research groups}

Pre-Question group: The plan used in teaching students in the Pre-question group involved activating their background knowledge through general discussion around the topic of the assigned text, using diagrams, asking relevant questions about ideas, phrases and key words. The target competence was the ability to identify the structure of the text, decode the meaning of words and perform word analysis tasks.

Genre group: The method employed in teaching students in the Genre group involved providing them with information on the generic structure of the texts, the register of Biology in the texts, and cohesive devices and rhetorical functions used in the texts. The target competence was the ability to distinguish main ideas from details, identify the author's attitude and structure of the texts, decode the meaning of words and perform word analysis tasks.

Pre-Question/Genre group: The method employed in teaching students in the Pre-question/Genre group involved combining the methods used for the Pre-question and Genre groups. The students' prior knowledge was activated through discussion, use of diagrams and questions. Genre knowledge was taught by providing information on the generic structure of the texts used, the register of Biology, cohesive devices and rhetorical functions used in the texts. The target competence was the students' ability to distinguish main ideas from details, identify the author's attitude, the structure of the text, decode the meaning of words and perform word analysis tasks.

Control group: This group of students did not receive any teacher input, they just read through the texts they were presented and answered the questions. They performed the following tasks: table completion exercise, word replacement and word analysis exercise. The teaching plan used for all the research groups is presented in Table 2 .

\section{Procedure for data analysis}

Data for this study were collected from students' responses to comprehension questions and questionnaires administered. Inferential statistics were used to analyse 
TABLE 2: Teaching plan used for the groups.

\begin{tabular}{|c|c|c|c|c|}
\hline Week & $\begin{array}{l}\text { Number of hours } \\
\text { for training }\end{array}$ & Task type $\&$ arrangement & Order of presentation of texts & Target competence \\
\hline 1 & 2 & $\begin{array}{l}\text { Answering multiple choice questions and short } \\
\text { answer questions }\end{array}$ & Focus on Bats & Ability to read the texts globally. \\
\hline 2 & 2 & $\begin{array}{l}\text { Detecting main ideas, details and attitude of the } \\
\text { author }\end{array}$ & $\begin{array}{l}\text { The Whale, The World of Microbes } \\
\text { and Man's Environment }\end{array}$ & $\begin{array}{l}\text { Ability to distinguish between main ideas, details and } \\
\text { detect the attitude of the author }\end{array}$ \\
\hline 3 & 2 & Signalling and cohesive devices & Morphology of Angiosperms & Ability to identify signal words and cohesive devices \\
\hline 4 & 2 & $\begin{array}{l}\text { Recognising the organisational structure of texts } \\
\text { and decoding the meaning of words }\end{array}$ & $\begin{array}{l}\text { The Bryophyta the Liverworts and } \\
\text { the Mosses }\end{array}$ & $\begin{array}{l}\text { Ability to identify the structure of the texts presented } \\
\text { indicate the meaning of words and perform word } \\
\text { analysis tasks }\end{array}$ \\
\hline
\end{tabular}

TABLE 3: ANOVA result on effect of instructional strategy and moderating variables on achievement in reading comprehension.

\begin{tabular}{|c|c|c|c|c|c|}
\hline Source & Type III sum of squares & $d f$ & Mean square & $F$ & Significance \\
\hline Corrected model & $48420.1 \mathrm{a}$ & 24 & 2017.5 & 13.0 & .000 \\
\hline Intercept & 24214.6 & 1 & 24214.6 & 157.0 & .000 \\
\hline Taper & 38678.7 & 1 & 38678.7 & 250.7 & .000 \\
\hline Experimental & 1164.8 & 3 & 388.2 & 2.5 & .059 \\
\hline Verbal & 1042.4 & 2 & 521.2 & 3.3 & .036 \\
\hline Gender & 85.6 & 1 & 85.5 & 0.5 & .457 \\
\hline Experimental * verbal & 1391.0 & 6 & 231.8 & 1.5 & .177 \\
\hline Experimental * gender & 324.0 & 3 & 108.0 & 0.7 & .553 \\
\hline Verbal * gender & 522.9 & 2 & 261.4 & 1.6 & .186 \\
\hline Experimental * verbal $*$ gender & 587.6 & 6 & 97.9 & 0.6 & .702 \\
\hline Error & 40097.8 & 260 & 154.2 & - & - \\
\hline Total & 692967.9 & 285 & - & - & - \\
\hline Corrected total & 88517.9 & 284 & - & - & - \\
\hline
\end{tabular}

Source: Fola-Adebayo, T, 'Effect of verbal ability on reading achievement: Implication for literacy empowerment', English Language Teaching Today 9, 43-52.

$R^{\prime}$ Squared $=.547$ (Adjusted R Squared $=.505$ )

the data, ANCOVA was employed and the hypothesis was tested at $P<0.05$ level of significance. This section presents the results of the data generated from quantitative and qualitative procedures.

\section{Results and discussion}

This study investigated the influence of two instructional strategies: Pre-question and Genre-based instruction on science undergraduates' achievement in, and attitude to, reading.

Hypothesis (Ho1): There is no significant effect of instructional strategy on the achievement of undergraduates in reading comprehension.

The result is presented in Table 3 and the information reveals that the main effect of instructional strategy is not significant on the achievement of the undergraduates in reading comprehension $\left(F_{(3,260)}=2.5 ; p>0.05\right)$. This means that the post-test mean scores of students in the Pre-question, Genre and Pre-question/Genre groups and Control groups do not differ significantly. On the basis of this finding, Hypothesis Ho1 is accepted. This indicates that there is no significant effect of instructional strategy on students' achievement in reading comprehension.

This result, which reveals that teacher-directed strategy instruction did not facilitate reading comprehension, differs from the findings of studies that indicate that strategy instruction enhanced reading comprehension (IsiuguAbanihe 1991; Tswanya 1995; Hyon 2001; Udosen 2002; Salataci \& Akyel 2002; Zwann \& Singer 2003; Ko 2005; Parvaz \& Salmani-Nodoushan 2007). The finding of this study may result from the fact that perhaps the time for training was too short for the students to fully internalise all they were taught.

Ho2: There is no significant effect of instructional strategy on the attitude of the undergraduates to reading.

Table 4 shows that the instructional strategy has a significant main effect on the attitude of the undergraduates to reading $\left(F_{(3,231)}=30.9 ; p<0.05\right)$. This means that there is significant difference in the attitude scores of students in the Prequestion, Genre, Pre-Question/Genre and Control group. The hypothesis is, therefore, rejected and this implies that the instructional strategy has a significant effect on the students' attitude to reading.

The Scheffe Test was conducted in order to determine significant differences with respect to each group's attitude to reading. The result shows that the Control $\bar{x}=122.5$, Genre $\bar{x}=122.9$ and Pre-question $\bar{x}=124.2$ groups had almost similar means, indicating that students in the three groups expressed very similar opinions about reading. Although the values were almost identical, the Pre-question had the highest mean; this was followed by the Genre and the Control group. Students in the Pre-question/Genre $\bar{x}=136.0$ group held the highest attitude mean score indicating they held the highest positive attitude to reading. The implication is that attitude to reading improved more when the Pre-question/ Genre strategy was used. The data are presented in Table 5.

This result, which indicates that the reading instruction led to a positive attitude to reading, may be explained by 
Table 4: ANOVA result on effect of instructional strategy and moderating variables on attitude to reading.

\begin{tabular}{|c|c|c|c|c|c|}
\hline Source & Type III sum of squares & $d f$ & Mean square & $F$ & Significance \\
\hline Corrected Model & $12861.6 a$ & 24 & 535.9 & 13.2 & .000 \\
\hline Intercept & 4349.7 & 1 & 4349.7 & 107.8 & .000 \\
\hline Attitude-Pre & 1266.2 & 1 & 1266.2 & 31.3 & .000 \\
\hline Experimental & 3743.8 & 3 & 1247.9 & 30.9 & .000 \\
\hline Verbal & 811.4 & 2 & 405.7 & 10.0 & .000 \\
\hline Gender & 233.6 & 1 & 233.6 & 5.7 & .017 \\
\hline Experimental * Verbal & 227.9 & 6 & 37.9 & 0.9 & .466 \\
\hline Experimental $*$ Gender & 261.8 & 3 & 87.2 & 2.1 & .093 \\
\hline Verbal * Gender & 25.4 & 2 & 12.7 & 0.3 & .730 \\
\hline Experimental $*$ Verbal $*$ Gender & 391.2 & 6 & 65.2 & 1.6 & .143 \\
\hline Error & 9315.3 & 231 & 40.3 & - & - \\
\hline Total & 4106618.0 & 256 & - & - & - \\
\hline Corrected total & 22177.0 & 255 & - & - & - \\
\hline
\end{tabular}

Source: Fola-Adebayo, T, 'Effect of verbal ability on reading achievement: Implication for literacy empowerment', English Language Teaching Today 9, 43-52.

$*$, moderating variables.

$R^{\prime}$ Squared $=.580$ (Adjusted $R$ Squared $=.536$ )

Table 5: Scheffe test showing group differences in attitude to reading.

\begin{tabular}{lcccc}
\hline Experimental group & $\boldsymbol{N}$ & & \multicolumn{2}{c}{ Subset } \\
\cline { 2 - 3 } \cline { 4 - 5 } \cline { 4 - 5 } & $\mathbf{1}$ & & $\mathbf{2}$ & $\mathbf{1}$ \\
\hline Control & 64 & & 122.5 & - \\
Genre & 68 & & 122.9 & - \\
Pre-Question & 61 & & 124.2 & - \\
Pre-Question/Genre & 63 & & - & 136.0 \\
Significance & - & & .578 & 1.000 \\
\hline
\end{tabular}

Means for groups in homogeneous subsets are displayed.

Based on Type III sum of squares.

The error term is mean square (Error) $=45.610$

Source: Fola-Adebayo, T, 'Effect of verbal ability on reading achievement: Implication

for literacy empowerment', English Language Teaching Today 9, 43-52.

the tricomponent view of attitude which emphasises the interrelationship of the cognitive, affective and conative dimensions of attitude. The advantage, which the students in the experimental groups had, over the Control group may be partly attributed to the nature of the strategies. The strategies by their nature may have exerted some cognitive and linguistic challenge on the students, with the result that the more involved they were in these activities, the more favourable their attitude towards reading became. The likely reason for the increase in the positive attitude, observed in the Control group, may result from interest in the reading material.

The result of this study is supported by findings from other research in the domain (Adelabu 1998; Jiboku 1998; Udosen 2002; Yamashita 2004), which reported higher attitude scores for the experimental group over the control group, and also different attitude scores for the experimental groups. When students develop strategies for reading specialised texts, they develop self-confidence which translates into positive attitude to reading. The fact that the reading materials were related to their study area may be responsible for their positive attitude to the texts.

Also the combination of the two methods may account for the superior attitude score of the Pre-question/Genre over the Pre-question, Genre and Control groups. Through the Pre-question strategy, an interactive process between the background knowledge of the reader and the text is evoked, while the genre approach helps students internalise the linguistic forms and structures that realise the structure of texts. Research in written discourse, genre analysis and rhetoric indicates that there are patterns in the organisation of texts which play significant roles in how readers process and engage with texts (Swales 1990:141).

\section{Qualitative analysis on gender and reading comprehension}

Qualitative data on gender and reading comprehension are presented in this section. The qualitative procedure was carried out through video-recording, and the objective was to provide supplementary data that would provide an explanation for the results obtained quantitatively.

\section{Results from qualitative data}

The data, obtained from the speech behaviour of the two genders from the two universities, reveal that although the men did not occupy much verbal space, they asserted authority over the female students by controlling and managing group activities and discussing and evaluating the responses of their female counterparts. Table 6 shows the details of the number of turns taken by male and female students from the two universities.

The data from Table 6 indicate that the women dominated most of the turns, with a total number of 199 turns as against 126 turns recorded for the male students. Interaction 1- FUNAAB reveals a total of 59 turns for women and 41 for men. Interaction 2-FUNAAB shows that the women recorded 36 turns whilst the men had 34 turns. For Interaction 3-FUNAAB the female students had a total of 32 turns whilst the male students had 28 turns. Finally Interaction 4-FUNAAB indicates that the women had 10 turns whilst the men had 4 turns. Data from the Federal University of Technology, Minna revealed a similar trend. Interaction-1 FUTM shows that the female students had more verbal space with a total of 24 turns whilst the men recorded none. Interaction 2-FUTM shows a total of 10 turns for the women and 9 turns for the men. Interaction 3-FUTM indicates that the women recorded a total of 12 turns and the male students had 10 turns. Interaction 4-FUTM reveals a total of 
TABLE 6: Number of turns taken by male and female students from FUNAAB and FUTM.

\begin{tabular}{|c|c|c|c|c|c|c|c|c|c|}
\hline University & FUNAAB Inter1 & FUNAAB Inter2 & FUNAAB Inter3 & FUNAAB Inter4 & FUTM Inter1 & FUTM Inter2 & FUTM Inter3 & FUTM Inter4 & Total turns \\
\hline Turns for male & 41 & 34 & 28 & 4 & 0 & 9 & 10 & 0 & 126 \\
\hline Turns for female & 59 & 36 & 32 & 10 & 24 & 10 & 12 & 16 & 199 \\
\hline
\end{tabular}

Source: Data compiled by author for the article.

Values are given as cardinal numbers.

16 turns for the women and no turns for the men. Classroom interaction from the University of Technology, Minna, reveals that the female students actively participated in group discussions.

The analysis of the turns taken revealed that the male students used discourse strategies to carve their identity as males and assert authority over the women. They used indirect speech acts to preserve their ego and maintain their public face. Boisterous behaviour was also employed to deride, intimidate and silence the women. The male students used these discourse strategies in reaction to the assertive and confident behaviour of the female students whose speech behaviour deviated from the expected 'norm'. Contrary to the view held by the dominant group, that male speech style is referred to as direct, succinct and instrumental, whilst female language is thought to be indirect, elaborate and affective (Lakoff 1973), the data from this study reveal that the women used language that was different from the assumed speech style of women. Analysis of the turns the women took shows that they used linguistic, pragmatic and paralinguistic strategies to challenge male responses and assert themselves. This was revealed in the forcefulness of their responses which was expressed through their use of strategies like stress, high tone and high pitch, they also used indirect speech acts and non-verbal signals to make their points. They used these strategies to articulate their points, express their opinions, undermine male views and enforce their views on their male counterparts.

\section{Recommendations}

In the light of the conclusions drawn from the study, the following recommendations are proffered:

- Teachers who teach EAP reading should employ Pre-question and Genre-based instructional strategies in teaching reading to science students, as this study revealed that activating background knowledge and raising the students' awareness about the generic features of texts can lead to positive attitude to EAP reading.

- Also reading teachers should use authentic texts that are drawn from the students' subject areas as this will lead to motivation and reading engagement (Cambourne 1995; Guthrie \& Wigfield 2000), and sustain students' interest in the reading event (Carrell 1988).

\section{Conclusion}

This study investigated the influence of two instructional strategies: Pre-question and genre-based instruction on the achievement of science undergraduates in reading comprehension and attitude to reading. It revealed that reading strategy instruction did not facilitate achievement in reading comprehension although it led to a positive attitude to reading in an EAP context. The Pre-question/Genre strategy was the most effective in influencing the attitude of students to reading. The need to challenge male hegemony, discredit male bias about female intellectual ability in SciTech, and assert their views as members of the same academic community accounted for the verbal space occupied by the women and their forceful response in class. On the other hand, the male students used discourse strategies to maintain dominance and control the classroom events.

\section{Acknowledgements}

I am grateful to students of the Federal University of Technology, Minna and the Federal University of Agriculture, Abeokuta, Nigeria who participated in this study and members of staff of the two universities who provided me assistance when this study was being conducted. My gratitude also goes to Emeritus Prof. A.I. Odejide under whose supervision this work was carried out.

\section{Competing interests}

The author declares that she has no financial or personal relationship(s) that may have inappropriately influenced her in writing this article.

\section{References}

Adelabu, B., 1998, The relative effectiveness of prequestion, outline and graphic organizers in undergraduates' achievement in reading comprehension and attitude to reading. Ph.D. Thesis. Dept. of Teacher Education, University of Ibadan.

Adesemewo, P.O., 1999, Effects of Robinson's SQ3R and summarisation techniques in improving comprehension among some secondary school students. Ph.D. Thesis. Dept. of Guidance and Counselling. University of Ibadan.

Adkins, A. \& McKean, I., 1983, Text to note: Study skills for advanced learners, Edward Arnold Publishers Ltd., London.

Anderson, R.C., 1984, 'Role of the reader's schema in comprehension, learning and memory', in R.C. Anderson, J. Osborn \& R.J. Tierney (eds.), Learning to read in American schools: Basal readers and knowledge texts, pp. 243-258, Erlbaum, Hillsdale, New Jersey.

Baker, L., 2003, 'The role of parents in motivating struggling readers', Reading and Writing Quarterly 19, 87-106.

Bhatia, V.K., 1993, Analyzing genre: Language use in professional settings, Longman, London.

Blumberg, R.L., 2007, 'Gender bias in textbooks: A hidden obstacle on the road to gender equality in education', Paper Commissioned for the EFA Global Monitoring Report 2008, Education For All By 2015: Will We Make It?, United Nations Educational, Scientific and Cultural Organization, New York.

Bodunde, H.A. 2006, 'An appraisal of reading comprehension skill and comprehension ability of pupils in Nigerian primary schools', English Language Teaching Today 5, 59-70.

Butler, Y.G., 2007, 'Children's reading attitudes in L1 and FL', Academic Exchange Quarterly Spring 2007.

Cambourne, B., 1995, 'Towards an educationally relevant theory of literacy learning twenty years of inquiry', Reading Teacher 49, 182-192. http://dx.doi.org/10.1598/ RT.49.3.1

Cameron, D., 1998, The feminist critique of language: a reading, 2nd edn., Routledge, London. 
Canagarajah, A.S., 2002, 'Globalization, methods, and practice in periphery classrooms', in D. Block \& D. Cameron (eds.), Globalization and Language Teaching, pp. 134-150, Routledge, London
Teassrooms', in D. Block \& D. Cameron

Carrell, P.L., 1988, 'Introduction: Interactive approaches to second language reading' in P.L. Carrell, J. Devine \& D.E. Eskey (eds.), Interactive Approaches to Second Language Reading, 1-8, Cambridge University Press 1, Cambridge.

Cheung, D. \& Ching, L.P., 1997, 'The genre analysis approach to technical report writing: A template or an analytic framework,' English for Specific Purposes Malaysia 5(1), 29-38.

Devine, J., 1988, 'A case study of two readers: Models of reading and reading performance', in P.L. Carrell, J. Devine \& D.E. Eskey (eds.), Interative approaches to second language reading, pp. 127-139, Cambridge University Press, Cambridge. $\mathrm{http}: / / \mathrm{dx}$.doi.org/10.1017/CBO9781139524513.015

Dudley-Evans, T., 1987, 'Genre analysis and ESP', English Language Research Journal 1(1), 1-9.

Ewusie, J.Y., 1980, Tropical biology, Harrap Ltd., London.

Fleischman, H.L., Hopstick, P.J., Pelczar, M.P. \& Shelly, B.E., 2010, 'Highlights from PISA 2009: Performance of US 15-year old students in Reading, Mathematics, and Science Literacy in an international context (NCES 2011-004), US Department of Education, National Center for Education Statistics, US Government Printing of Education, National
Office, Washington, DC.

Fola-Adebayo, T., 'Effect of verbal ability on reading achievement: Implication for literacy empowerment', English Language Teaching Today 9, 43-52.

Grabe, W. 2004, 'Research on teaching reading', Annual Review of Applied Linguistics 24, 44-69.

Guthrie, J.T. \& Wigfield, A., 2000, 'Engagement and motivation in reading', in M.L. Kamil, P.B. Mosenthal, P.D. Pearson \& R. Barr. (eds.), Handbook of reading research, pp. 403-422, Erlbaum, Mahwah, New Jersey.

Hock, M. \& Mellard, D., 2005, 'Reading comprehension strategies for adult literacy Outcomes', Journal of Adolescent and Adult Literacy 49(3), 192-200. http://doi. org/1598/JAAL.49.3.3

Hyon, S., 2001, 'Long-term effects of genre-based instructions: a follow-up study of an EAP reading course,' English for Specific Purposes 20, 417-438. http://dx.doi. org/10.1016/S0889-4906(01)00019-9

Jiboku, A.O., 1998, The relative effectiveness of critical reading and semantic mapping, instructional strategies on secondary school students' learning outcomes reading comprehension. PhD. Thesis. Dept. of Teacher Education, University of Ibadan.

Kay, V., 1985, Biological sciences: Developing reading skills in English, Pergamon Press, Hemel Hempstead.

Kintsch, W. \& Rawson, K.A., 2005, 'Comprehension', in M.J. Snowling \& C. Hulme (eds.), The Science of Reading, pp. 209-226, Blackwell, Malden. http://dx.doi. org/10.1002/9780470757642.ch12

Khamati-Njenga, B. \& Clancy, J., 2005, Concepts and issues in gender and energy, ENERGIA, Leusden.

Ko, M.H., 2005, 'Glosses, comprehension and strategy use', Reading in a Foreign Language 17(2), 125-143.

Lakoff, R., 1973, 'Language and woman's place', Language in Society 2, 45-79. http:// dx.doi.org/10.1017/S0047404500000051

Mathewson, G.C., 1994, 'Model of attitude influence upon reading and learning to Read', Theoretical Models and Processes of Reading, in R.B. Ruddell, M.R. Ruddell \& H. Singer (eds.), International Reading Association, 4th edn., Newark, Delaware.

Mathewson, G.C., 2004, 'Model of attitude influence upon reading and learning to read', in R.B. Ruddell \& N.J. Unrau (eds.), Theoretical Models and Processes of Reading, 5th edn., International Reading Association, pp. 1431-1461, Newark, Delaware.

McKenna, M.C., Kear, D.J. \& Ellsworth, R.A., 1995, 'Children's attitudes toward reading: a national survey,' Reading Research Quarterly 30, 934-956. http:// dx.doi.org/10.2307/748205

Mckenna, M.C., Conradi, K., Lawrence, C., Jang, B.G. \& Meyer, J.P., 2012, 'Reading attitudes of middle school students: Results of a U.S. survey', Reading Research Quaterly 47(3), 283-305.

Nwogu, K.N., 1991, 'Structure of science popularization: a genre-analysis approach to the schema of popularized medical texts', English for Specific Purposes 10.

Nwosu, F.C., 2002, Effects of four holistic instructional strategies on senior secondary school students' reading comprehension in Ibadan, Nigeria. PhD. Thesis. Dept. of Teacher Education, University of Ibadan.

Nzinga, K.N., 1983, 'Aspects of reading problems and their implications for academic achievement among new entrants at University of Ilorin', Journal of the Reading Association of Nigeria 1, 379-398.
Obah, T.Y., 1981, 'Some psycholinguistic factors affecting reading performance: a study of Nigerian university students', Journal of Language Arts and Communication 3(4), 169-186.

Odejide, B., 1979, 'Some aspects of appropriateness in Nigerian student writing', in E. Ubahakwe (ed.), Varieties and Functions of English in Nigeria, pp. 127-136, African Universities Press and Nigeria English Studies Association, Ibadan.

Odejide, A.I., 2003, 'English for academic purposes in Nigerian Universities of Technology: What methodologies?', English Language Teaching Today 2(1), 1-6.

Odiaka, S.I., 2002, Holistic and subskill instrumental approaches and content area reading comprehension among some junior secondary schools in Ibadan metropolis, PhD. Thesis, Dept. of Teacher Education, University of Ibadan.

Olorode, O. \& Illoh, H.C., 2000, Variety of forms in the plant kingdom, Bolakay Color Prints and Publishers, lle-Ife.

Osundina, M.A., Oloke, J.K., Fawole, O.O. \& Liasu, M.O., 1998, Diversity of organisms, Associated Book-Makers, Nigeria Ltd., Ibadan.

Oyetunde, T.O., 2002. 'Second language reading: Insights from Nigeria primary schools', The Reading Teacher 55(8), 748-755.

Parvaz, M.H. \& Salmani-Nodoushan, M.A., 2007, 'How does text cohesion affect reading comprehension?', Iranian Journal of Language Studies 1, 57-64.

Pearson, P.D. \& Johnson, D.D., 1978, Teaching reading comprehension, Holt, Rhinehart and Winston, New York.

Perfetti, C.A., Landi, N. \& Oakhill, J., 2005, 'The acquisition of reading comprehension skill', in M.J. Snowling \& C. Hulme, (eds.), The Science of Reading, pp. 227-247, Blackwell Publishing, Malen.

Petscher, Y., 2010, 'A meta-analysis of the relationship between student attitudes towards reading and achievement in reading', Journal of Research in Reading 33(4), 335-355. http://dx.doi.org/10.1111/j.1467-9817.2009.01418.x

RAND Reading Study Group, 2002, Reading for understanding: Toward an $R$ and D program in reading comprehension, RAND, 11, Santa Monica, California.

Robinson, P., 1991, ESP today: A practitioner's guide, Prentice Hall, Hemel Hempstead.

Rumelhart, D.E., 1984, 'Understanding', in J. Flood. (ed.), Understanding Reading Comprehension: Cognition, Language and the Structure of Prose, p. 2, International Reading Association, Newark, Delaware.

Russ, K.M., 1989, 'Relating reading attitude to reading achievement in an East Los Angeles junior high school', Reading Improvement 26(3), 208-214.

Salataci, R. \& Akyel, A., 2002, 'Possible effects of strategy instruction on L1 and L2 Readings,' Reading in a Foreign Language 14(1), 1-17.

Segun, A., 1998, Tropical Zoology, University Press, PLC, Ibadan.

Steffensen, M.S. \& Joag-Dev, C., 1984, 'Cultural knowledge of reading', in J.C. Alderson \& A.H. Urquhart (eds.), Reading in a Foreign Language, Longman, New York.

Swales, J.M., 1981, 'Aspects of article introduction', ESP Research Report, No 1, The University of Aston in Birmingham.

Swales, J.M., 1990, Genre analysis: English in academic and research settings. Cambridge, Cambridge University Press.

Tannen, D., 2003, 'Gender and family interaction', Handbook on Language and Gender, in J. Holmes \& M. Meyerhoff (eds.), Basil Blackwell, Cambridge, Mass and Oxford.

Templer, B., 2004, 'High-stakes testing at high fees: Notes and queries on the international English proficiency assessment market', Journal for Critical Education Policy Studies 2(1), 2.

Trabasso, T. \& Bouchard, E., 2002, 'Teaching readers how to comprehend text strategically', in C.C. Block \& M. Pressley (eds.), Comprehension instruction: Research-based practices, pp. 176-200, The Guilford Press, New York.

Tswanya, S.K., 1995, The relative effectiveness of schema activation and exploitation of linguistic cohesive devices on reading comprehension. PhD. Thesis, Dept. of Language Arts, University of Ibadan.

Udosen, A.E., 2002, Effects of two metacognitive instructional strategies on students' achievement in higher order reading comprehension and affective learning outcomes in Uyo, Nigeria, PhD. Thesis, Dept. of Teacher Education, University of lbadan.

Unoh, S.O., 1980., 'Reading problems in secondary school: Some observations and research findings', Journal of Language Arts and Communication 1, 30-40.

Yamashita, J., 2004, 'Reading attitudes in L1 and L2, and their influence on L2 extensive reading', Reading in a Foreign Language 16, 1.

Zhang, L.J. \& Wu, A., 2009, 'Chinese senior high school EFL students' metacognitive awareness and reading-strategy use', Reading in a Foreign Language 21(1) 37-59. 